\title{
The Nature of the Double Spireme in Allium Cepa.
}

\author{
BY \\ T. REED, A.R.C.SC., \\ Senior Demonstrator in Biology at Guy's Hospital Medical School (University of London), \\ London, S.E.
}

With Plates XVIII and XIX.

LLIUM CEPA has repeatedly been the subject of cytological investi-
gation, but there are several phases in its nuclear history which cannot be regarded as being clearly understood.

In the present investigation attention has been more particularly focused on the following points : the development and significance of the longitudinal fission in the spireme ribbon, the method of origin and grouping of the chromosomes in the prophases, and the origin and subsequent fate of the nucleoli.

In view of the recent investigations of Dr. Lawson $(10,11,12)$ on the significance of nuclear osmosis as a factor in mitosis, the behaviour of the nuclear vacuole and its contents during the prophases has also been carefully studied.

\section{Methods.}

Root apices have been almost exclusively used in the investigation. These were removed from plants which were grown in culture solutions or in soil. The bulbs used for the production of the roots were Sutton's 'Reading' and 'Ailsa Craig'.

The fixatives employed were Flemming's strong and weak solutions, either full strength or diluted with an equal volume of water, Hermann's fluid, and Farmer's acetic alcohol. Various strengths of chrom-acetic acid solutions were used, but were not found to be satisfactory.

In staining, Breinl's combination was extensively used and gave the best results, but Flemming's triple stain and Heidenhain's haematoxylin were also employed.

The sections were cut $2 \mu-14 \mu$ in thickness.

\section{Prophases.}

During the nuclear ' resting' stages the bulk of the chromatin is stored in the nucleoli ; the remainder of the nucleus contains a fine faintly staining reticulum. Where these threads of the reticulum cross one another a slightly

[Annals of Botany, Vo1. XXVIII. No. CX. April, 19I4.] 
more granular structure may be seen, but this does not stain with chromatin dyes. This reticulum appears to differ very little from the general cytoplasm of the cell (Pl. XVIII, Fig. I). It is impossible to say (at this stage) whether the threadwork is a continuous structure or not, but subsequent events suggest that it is of the nature of a thin fenestrated sphere.

One or more nucleoli may be present, and these are formed by subdivision in the hour-glass fashion described by Digby (1) for Galtonia.

The first indications of approaching mitosis are seen in the nuclear reticulum. The chromatin begins to aggregate in small band-like masses on this framework, as shown in Pl. XVIII, Fig. 2. It slowly spreads itself and builds up the spireme ribbon. It may have the granular structure of Pl. XVIII, Figs. 3 and 4 , or it may be fairly homogeneous, as in Pl. XVIII, Figs. 5 and 6. Grégoire (7) maintains for Allium Cepa, and probably for all somatic nuclei, the existence of a discontinuous spireme. This point is extremely difficult of interpretation, for, when first formed, the spireme is a much-coiled structure, and the coils are often closely wrapped about the nucleolus (P1. XVIII, Figs. 6 and 7), but there appears to be little doubt that at this stage it is a continuous ribbon. The ribbon is coiled quite irregularly (Pl. XVIII, Figs. 6, 7, 8) within the nuclear vacuole; no indication is seen of the arrangement into sixteen loops described by Schaffner (20).

The nucleoli are intimately associated with the formation of the spireme. Even in the 'resting' stages (Pl. XVIII, Fig. I) they may show fine fibrils of stainable matter radiating out to the nuclear reticulum. During the organization of the spireme these fibrils stain more densely (P1. XVIII, Figs. 5 and 6), and there seems little doubt that substances are passing out from the nucleoli from which the chromatic spireme is built. When the chromatin band is fully formed, the nucleoli are left as faintly staining bodies, often vacuolated, and still later they may be seen extruded into the cytoplasm (Pl. XVIII, Fig. I6). No fragmentation of the nucleoli was seen as described by Digby (1) for Galtonia.

Their ultimate fate was not followed, but it seems probable that they may become absorbed by the cytoplasm, for no trace of the core was ever seen in the cytoplasm of the daughter cell.

During the 'resting' stages the nucleoli often contain regularly shaped, highly refracting bodies, as shown in P1. XVIII, Fig. I $\alpha$. Leitgeb (13) and Digby (1) have described these bodies in the cells of Galtonia candicans, \&c. The latter observer suggests that these structures probably originate from the nucleolus. In the present instance there can be no doubt that this is the case, since they are actually situated within the nucleolus. Unlike the structures in Galtonia, which stain with chromatin dyes, these in $A$. Cepa appear to be unstained. The structures are apparently absorbed during the 
development of the spireme, for when the latter is complete they have disappeared, and, as was shown above (Fig. I6), the nucleolar core is left as a faintly staining body within the cytoplasm (P1. XVIII, Fig. I6).

These bodies may simply represent waste material produced by the nucleus during the 'resting' stages, which material might then diffuse into the cytoplasm during the early stages of mitosis, or represent some substance which is used in the process of organization of the spireme.

No useful purpose would be served here by detailing the various views which have been held as to the possible function of the nucleolus. It seems quite certain that it is a storehouse of reserve material which is used up in the formation of chromatin, but this may be only one of its functions.

From the early stages of its formation the spireme is seen to be a double structure. At first it consists of a double series of irregularly shaped granules lying side by side in the nuclear framework (Pl. XVIII, Figs. 3 and 4). Grégoire (7) has described this structure for several species of Allium, and has pointed out that the doubling is brought about by an alveolization of the chromatin band. Lundigård (14) also describes the split spireme for Allium. These observations also bear out Grégoire's (7) statement that the spireme is not built up of chromatin discs on a linin framework. No evidence is found to support the observations of Merriman (15) that the thread is a quadripartite structure.

The separation of the spireme into two parallel longitudinal bands is regarded as a definite fission, and, as will subsequently be shown, the split first makes its appearance in the anaphases of the preceding divisions, and not at the metaphase of the same division, as described by Schaffner (20), or the prophase, as stated by Grégoire (7), who says 'the longitudinal division is essentially a prophase phenomenon'.

The more or less isolated granules of the early spireme spread themselves over the nuclear groundwork and form a fairly homogeneous ribbon (Pl. XVIII, Figs. 6, 7, and 8). It is at this stage that the spireme becomes segmented. At first it appears to break up into a number of lengths. The number is, in all probability, eight, and each segment is a long, often twisted, double band. These segments are usually bent somewhere near their middle, and it is common to find the parts on either side of the bend with similar configurations (Pl. XVIII, Figs. 9, I0, I I, I2, and I3). Later these subdivisions break across transversely, and the sixteen chromosomes which characterize the somatic cells appear (Pl. XVIII, Figs. I4, I5, I6, and I 7). In other words, there appears to be a preparation at this stage for the paired arrangement of the chromosomes, which will be described presently.

A short digression must be made here to describe other changes which have been taking place in the nucleus during the prophases.

The 'resting' nucleus occupies about half the cell volume (Pl. XVIII, Fig. I) ; the organization of the spireme involves a very considerable increase 
in size of the nuclear vacuole, so much so that Lawson $(10,11$, and 12) has termed these prophases the 'growth period'.

During the early stages of the prophase the nuclear vacuole has a very definite boundary-the so-called nuclear membrane. The growth of the vacuole is accompanied by the stretching or by the growth of this boundary to keep pace with the increased volume. Whilst the distension of the vacuole is progressing, the chromatic elements become closely pressed to its surface, so that there is little doubt that this growth is a result of increased turgidity due to the metabolic processes which must be taking place, and which result in the formation of the spireme segments.

The increased size of the nuclear vacuole is accompanied by a corresponding diminution in definiteness of its boundary. As the older stages of prophase are reached, the nuclear vacuole occupies almost the whole of the cell space, and some of the chromosomes have passed out into the general cytoplasm (Pl. XVIII, Figs. 9, IO, II). Finally, the limits of the vacuole appear merely as a faint, irregular boundary of cytoplasm (Pl. XVIII, Figs. 9, 10, I4, I5, I6) without the slightest suggestion of a definite membrane as a distinct entity, which is suggested by Lawson (11), Němec (18), Merriman (15), and others.

Further, the form of the vacuole is not necessarily ' perfectly spherical', as described by Lawson (p. 154, 10) for $A$. Cepa. It may be quite irregular in outline, and is sometimes even bilobed (Pl. XVIII, Fig. I $b$ ), although this latter condition is not of frequent occurrence. Farmer (2) has shown that the form of the vacuole will not be determined by osmotic pressure alone, but that surface tension will play a part in the determination of its shape.

When the vacuole has reached its full size Lawson maintains that it collapses and that the nuclear membrane becomes wrapped around each chromosome. The collapse, according to this author, is followed by the drawing in of the cytoplasm, which is consequently compelled to assume a radiate structure, in which he sees the beginnings of the formation of the achromatic spindle.

No evidence whatever is found in the present investigation which supports these conclusions. The ragged edge of the cytoplasm can be recognized even when the chromosomes are passing on to the equatorial plate (Pl. XVIII, Fig. I6).

This is not the place to discuss the bearing of the above conclusion on the synaptic contraction during the heterotype mitoses, but it may be remarked that no useful purpose would be served by giving series of measurements showing the increase in size of the nuclear vacuole or the volume of the chromatin mass. This method of comparison would only be useful if the nuclei were of similar sizes and if they contained equal volumes of chromatin. In the somatic nuclei of $A$. Cepa it can hardly be assumed that the latter supposition is valid, whilst the former can easily be shown to be untrue. 
To return to the prophases. When the sixteen chromosomes have been organized they pass on to the equatorial plate, and there they are seen to be arranged in pairs (Pl. XVIII, Figs. 16 and 17$)$. The pairing is suggested not only by the approximation of the chromosomes, but also by the fact that members of a pair often show a similarity of form and size. It is not always possible to make out eight distinct pairs, but this is probably due to the fact that some of them lag behind the others in taking up their position, and that they are seen from different angles. Further, it seems probable that the members of a pair are both derived from the same subdivision of spireme (P1. XVIII, Figs. 10, I6, I7). Müller (16) has recently shown that a similar pairing of chromosomes takes place in $Y u c c a$, but only among the larger chromosomes. Grégoire (8) denies the existence of paired chromosomes for $A$. Cepa. Gates (6) and Strasburger (22) have also described pairing of chromosomes in Oenothera and Pisum respectively, and Stomps (21) in the somatic nuclei of Spinacia oleracea.

\section{MetAPHASE.}

Details of the method of attachment of the chromosomes to the spindle fibres have not been followed.

The chromosomes become $\mathrm{V}$-shaped or form loops with one longer and one shorter arm.

Grégoire (8) states that they become attached by their bent parts, and that these are the first parts to separate. This is undoubtedly a common occurrence, but the ends sometimes separate before the middle parts (Pl. XVIII, Fig. I 7 ).

Pl. XVIII, Figs. I7, I8, 19, 20, 21, and 22, show the separation of the daughter chromosomes. It will be noticed by a comparison of the figures that the split previously observed in the prophase is the one which now brings about the separation of the daughter chromosomes.

Sometimes the longitudinal split closes up during the later stages of prophase, and it should be noticed that when this is the case the re-formed split shows first of all as a series of vacuoles which gradually fuse and effect the separation of the daughter chromosomes (Pl. XVIII, Figs. 2I, $22 a$ ).

\section{ANAPHASES.}

As the daughter chromosomes pass to the poles they retain their $\mathrm{V}$ - or loop-shaped forms ; they seldom appear to be straightened out in the passage to the poles of the spindle.

During the separation of the chromosomes the arrangement in pairs still remains evident (P1. XVIII, Figs. 23 and 24). It should further be noticed that the members of a pair are very similar in form. The pairing cannot be seen amongst the whole sixteen chromosomes, but this is probably 
due to the fact that they are closely massed together, for it will be noticed that the pairing is extremely well seen in the chromosomes which stand out from the general tangle.

Attention should be directed to the chromosomes $x$ of Pl. XVIII, Figs. 22, 23, and 24, which are quite different in form from the others, and may therefore be termed 'hooked' chromosomes.

It is whilst the daughter chromosomes are passing to the poles that the beginnings of the longitudinal fission are effected. It makes its appearance as a series of slits (P1. XVIII, Figs. 22 $b, 23$, and 24). At this stage no lateral attachments between neighbouring chromosomes have been effected, so that in this case the split is not due to the lateral attachments pulling out the chromosomes, as suggested by Fraser and Snell (6) for Vicia.

\section{TELOpHASE.}

Lateral attachments between neighbouring chromosomes are now freely effected (P1. XVIII, Figs. 25, 26, and 27). The free ends of the chromosomes are drawn inwards and fusions take place between these free ends, the result being that a somewhat flattened nucleus is formed in which the chromatin is present as a flattened sphere with rather large spaces in it (Pl. XVIII, Fig. 26). This is later followed by the expansion of the nucleus and the assumption of an oval or rounded form. With the distension of the nucleus the slits previously observed in the anaphase naturally become much larger, since now all the chromosomes are more or less connected one with another and form a hollow sphere. Polar views of the nucleus show that the sixteen chromosomes can still be recognized (P1. XVIII, Fig. 28), although, as has been pointed out above, fusions take place between neighbouring chromosomes.

At this stage one or more chromatin knots have been formed on some part of the chromatin sphere (Pl. XVIII, Fig. 28). Each knot later develops the characteristic nucleolar vacuole, so that there is little doubt that they represent the beginnings of the formation of the nucleoli.

As the nucleus passes further into the resting stage the amount of chromatin diminishes in the nuclear network and increases in the nucleolus, the splits in the network open out still further, and finally the nucleus consists of the faintly staining fenestrated sphere almost entirely devoid of stainable matter.

During the telophases an enormous number of cross-connexions are made between neighbouring chromosomes, so that the boundaries of each become difficult to follow. A recognizable foundation for each chromosome cannot be seen during the resting stages, such as is suggested by Grégoire (7) for Allium, Müller (17) for Najas marina, and Overton (19) for Calycanthus, \&c. 


\section{Mitosis IN THE GAMETOPHyte.}

It has been shown above that $A$. Cepa has a longitudinally split spireme in its somatic nuclei.

The nuclei of the pollen-grains have been examined, and it may be stated at once that they also show a similar type of spireme to that present in the somatic cells.

Pl. XIX, Fig. 29, shows the 'roof' of a nucleus, and at this early stage it will be seen that the chromatin bands show well-marked splits. Pl. XIX, Fig. 30, shows a slightly older nucleus, and here again the longitudinal fission is apparent. The spireme which is ultimately formed is rather stout, and although it may not show the extensive splitting seen in Pl. XVIII, Figs. IO, II, and I2, of somatic nuclei, there can be no question that a split exists (P1. XIX, Figs. 31, 32, and 33). It is during the last stages of prophase only that the longitudinal fission is obscured, and this is precisely the stage at which it is least obvious in the somatic nuclei. Pl. XIX, Fig. 34, however, shows a well-marked fission in one of the very stout and deeply staining chromosomes.

The nucleus need not be followed through the subsequent phases of division since enough has been seen to clearly demonstrate that, apart from the chromosome number, there is no essential difference in the appearance of the spiremes in the somatic and gametophytic nuclei of $A$. Cepa.

It may, however, be pointed out that, as the generative nucleus passes into the resting stage, it becomes very much elongated and eventually suggests a vermiform type of nucleus; at the same time a well-marked vacuole is formed around it and the nucleus becomes suspended in this space by a spindle-shaped sheath of cytoplasm (Pl. XIX, Figs. 35 and $3^{6}$ ). Both these nuclei also show distinct evidence of longitudinal fission in their chromatic elements.

\section{Discussion.}

It is not proposed to discuss fully the results of this investigation at the present stage; other phases in the nuclear history are being examined, so that a full discussion must necessarily be left to a later date, when all the facts may be brought into line. Certain points, however, may be emphasized here.

It has been shown that both the somatic and the gametophytic nuclei have the double or longitudinally split type of spireme. This type of spireme in somatic cells is regarded by Overton (19), Sykes (23), and Takara (24) as representing a lateral approximation of the structures derived from the male and female gametes respectively, whilst Farmer and Digby ( 1 and 4 ) and Hof (9) regard it as representing a premature longitudinal fission which will effect the separation of the daughter chromosomes at the next division. 
If any pairing of allelomorphs takes place at all it is obvious that the double type of spireme can hardly represent this phenomenon in $A$. Cepa, for the same type of spireme has been shown to exist in gametophytic cells where there can be no question of pairing of homologous chromosomes. It seems, rather, that this phenomenon is indicated by the pairs of chromosomes of similar form which may be seen in the prophases, metaphases, and anaphases of somatic cells. During these three phases of nuclear division there is ample opportunity for any interaction between the members of chromosome pairs.

In any case it now seems clear that in Allium Cepa, as in Vicia Faba, the double type of spireme does not represent the paternal and maternal threads lying side by side. It does appear certain, however, as pointed out by Farmer and Digby ( 1 and 2), Farmer and Shove (3), and Fraser and Snell (5), that it merely represents the premature fission of the chromosomes, a fission which is generally effected at the anaphase or telophase of the division preceding that at which it will become operative.

It has also been shown that in $A$. Cepa the longitudinal fission is recognizable at the anaphase of the preceding division and not the telophase as in Vicia Faba, and also that the fission is not effected by the pull of the lateral attachments between adjacent chromosomes, but that such lateral attachments merely accentuate a fission already formed within the chromosome. It would be extremely interesting to know exactly what brings about the fission at this early stage.

Further, the presence of a chromosome of a definite form - the hooked chromosome, $x$ in Pl. XVIII, Figs. 22, 23, and 24-suggests that we may have here a feature of some special biological importance, but until it can be traced through all the nuclear phases of the plant it would be unwise to endow it with any particular function.

Finally, it may again be remarked that the facts which have emerged from this investigation lend no support to Lawson's recently propounded theories $(10,11,12)$ to account for certain phenomena of mitosis. It has not been found possible to demonstrate in $A$. Cepa the presence of a nuclear membrane as a distinct entity, nor is it found that there is any sudden collapse of the nuclear vacuole which might call the spindle into being. It is quite true that Lawson's results were mainly derived from the study of meiotic cells, but he maintains that the processes are the same in both meiotic and somatic cells.

\section{SUMMARY.}

I. At the end of prophase chromosomes are arranged in eight pairs on the equatorial plate and the members of each pair roughly correspond with one another in form.

3. The paired arrangement is preserved during the anaphases. During 
the anaphase the fission which will effect the separation of the daughter chromosomes at the subsequent division is marked out. During the stages ' hooked chromosomes' may be seen.

3. In the telophases lateral fusions take place between the chromosomes, and this has the effect of making the fission more evident.

4. A chromatin knot is formed by the fusion of parts of chromosomes and gives rise to the nucleolus. During the prophase the reverse series of changes take place; the nucleolus gives up its chromatin to the developing spireme.

5. In the 'resting' stages the nucleus consists of a faintly staining reticulum. The chromatin is stored in the nucleoli, and these are joined to the reticulum by the fine fibrillar connexions.

6. The spireme, which is longitudinally split, appears to be continuous at first, but later segments into eight subdivisions, and finally these segment and give rise to sixteen chromosomes.

7. No evidence is found in favour of the theory that the sudden collapse of the nuclear vacuole is responsible for the appearance of the achromatic spindle.

8. It was not found possible to demonstrate the presence of a distinct nuclear membrane.

9. The gametophytic nuclei, like the somatic, show the double type of spireme.

My heartiest thanks are tendered to Dr. H. C. I. Gwynne-Vaughan (Fraser) for providing facilities for the undertaking of this work in the laboratory of Birkbeck College and for valuable criticism during its progress.

\section{BIBLIOGRAPHY.}

1. Digby, L.: The Somatic, Premeiotic, and Meiotic Nuclear Divisions of Galtonia candicans. Ann. Bot., vol. xxiv, p. 727 .

2. Farmer, J. B. : 'Nuclear Osmosis' and its Assumed Relation to Nuclear Division. New Phyt., vol. xi, p. I 39 .

3. Farmer, J. B., and Shove, D.: The Structure and Development of the Somatic and Heterotype Chromosomes of Tradescantia virginica. Quart. Journ. Mic. Sc., vol. xlviii, p. 559.

4. Farmer, J. B., and Digby, L.: Somatic and Heterotype Mitoses in Galtonia candicans. B. A. Report, Sheffield, igro.

5. Fraser and Snell: The Vegetative Divisions of Vicia Faba. Ann. Bot., vol. xxv, p. 845.

6. Gates, R. R.: Somatic Mitoses in Oenothera. Ann. Bot., vol. xxvi, p. 993.

7. Grégoire, V. : La structure de l'élément chromosomique dans les cellules végétales. La Cellule, t. $x x i i i, 2^{\mathrm{e}}$ fascicule, p. $3^{\mathrm{II}}$.

8. - Les phénomènes de la métaphase et de l'anaphase dans la caryocinèse somatique. Ann. de la Soc. Sc. de Bruxelles, t. xxxvi.

9. HoF, A. C. : Histologische Studien an Vegetationspunkten. Bot. Centralbl., Bd. lxxvi, p. 22 I. 
10. Lawson, A. A.: Nuclear Osmosis as a Factor in Mitosis. Trans. Roy. Soc. Edin., vol. xlviii, p. 137 .

11. $:$ The Phase of the Nucleus known as Synapsis. Trans. Roy. Soc. Edin., vol. xlvii, p. 59 I.

12. - A Study in Chromosome Reduction. Trans. Roy. Soc. Edin., vol, xlviii.

13. Leitgeb, H.: Krystalloide in Zellenkernen. Mitt. aus dem Bot. Inst. zu Graz, Jena, p. i 5 .

14. LundigÅR, H.: Ueber Kerntheilung in den Wurzelspitzen von Allium. Svensk Botanisk Tidskrift, Bd. iv, p. I 88.

15. Merriman, M. C.: Vegetative Cell-division in Allium. Bot. Gaz., vol. xxxvii, p. i 78.

16. Muller, H. A. C. : Ueber karyokinetische Bilder in der Wurzelspitze von Yucca. Pringsh. Jahrb. f. wiss. Bot., Bd. xlvii, p. 99 .

17.

18. Nemec, B.: Ueber die karyokinetische Kerntheilung in der Wurzelspitze von Allium Cepa. Pringsh. Jahrb. f. wiss. Bot., Bd. xxxiii.

19. Overton, J. B. : On the Organization of the Nuclei in the Pollen Mother-cells of Certain Plants. Ann. Bot, vol. xxiii, p. I9.

20. Schaffner, J. H.: Karyokinesis in Root Tips of Allium Cepa. Bot. Gaz., vol. xxvi, p. 225.

21. Stomps, T. J. : Kerndeeling en synapsis bij Spinacia oleracea. Amsterdam, 1910.

22. Strasburger, E. : Ueber die Individualität der Chromosomen und die Pfropfhybriden-Frage. Pringsh. Jahrb. f. wiss. Bot., Bd. xliv, p. 482 .

23. Sykes, M. G.: Note on the Nuclei of some Unisexual Plants. Ann. Bot., vol. xxiii, p. 341.

24. Takara, M. : Ueber Kernteilung bei Morus. Bot. Mag. Tokyo, vol. xxiv, p. 28I.

\section{EXPLANATION OF PLATES XVIII AND XIX.}

Illustrating Mr. T. Reed's paper on the Nature of the Double Spireme in Allium Cepa.

All figures were drawn with camera lucida under a $2 \mathrm{~mm}$. apoch. hom. imm. Swift obj. and oc. 12 and 18. Magnification $\times 145^{\circ}$ and $\times 2100$.

\section{PLATE XVIII.}

Fig. I. 'Resting' stage, showing chromatin in nucleoli; lower nucleolus shows fibres joining it to faintly staining nuclear reticulum. $\times 145^{\circ}$.

Fig. I $a$. Nucleoli with crystalline bodies. $\times 145^{\circ}$.

Fig. 16 . Nucleus with bilobed form. $\times 145^{\circ}$.

Fig. 2. Early prophase showing commencement of spireme formation. $\quad \times 145^{\circ}$.

Figs. 3-4. Later stage of same. $\times \mathrm{r}_{45}$.

Fig. 5. Spireme with prominent nucleolar connexions. $\times 145^{\circ}$.

Fig. 6. Later stage of same; nucleolus with crystalline body. $\times 145^{\circ}$.

Fig. 7. Spireme, showing close relation with nucleolus. $\times 1450$.

Fig. 8. Spireme with well-developed fission. $\times 145^{\circ}$.

Figs. 9-I 3. Segmentation of spireme to form subdivisions. $\times 1450$.

Figs. 14, I5. The full number of somatic chromosomes formed. $\quad \times 1450$.

Figs. I6, I 7 . Pairing of chromosomes on equatorial plate as seen in polar view. I6 6 I 450 . I $7 \times 2100$.

Figs. I8, 19, 20. Metaphases showing the opening of the fission which will effect the separation of the daughter chromosomes. $\times 145^{\circ}$.

Fig. 2I. The chromosomes showing development of 'vacuoles' which will bring about their fission. $\times 2100$.

Figs. 2a $a$ and $22 b$. Hooked chromosomes (a) from a metaphase, (b) from an anaphase. $\times 2100$ 
Reed.- The Nature of the Double Spireme in Allium Cepa. 28 I

Fig. 23. Anaphase, pairing well seen in lower group. 'Hooked' chromosome $(x)$ also shown. $\times 145^{\circ}$.

Fig. 24. Similar to Fig. 23 with 'hooked' chromosome $(x)$, also showing commencement of longitudinal fission. The four large dots represent the arms of a pair of chromosomes cut transversely. $\times \mathrm{I} 450$.

Figs. 25, 26. Telophases, lateral fusions between chromosomes effected, and pulling out of the 'slits'. $\times 1450$.

Fig. 27. Later telophase. $\times 145^{\circ}$.

Fig. 28. Polar view of telophase, showing the sixteen chromosomes and nucleolar knot with characteristic nucleolar vacuole. $\times 145^{\circ}$.

\section{PLATE XIX.}

Fig. 29. Pollen-grain nucleus. 'Roof' of nucleus, showing the split spireme. $\quad \times \quad \mathrm{I} 45^{\circ}$.

Fig. 30 . Older pollen-grain nucleus with well-marked split spireme. $\times \quad x_{450}$.

Fig. 31. Generative nucleus with longitudinally split spireme. $\times 1450$.

Fig. 32. Prophase of pollen-grain nucleus with split spireme. $\times \mathrm{I}_{4} 5^{\circ}$.

Fig. 33. Later spireme in pollen-grain. $\times 145^{\circ}$.

Fig. 34. Portion of pollen-grain nucleus with one chromosome longitudinally split. $\quad \times \quad$ I 450 .

Figs. $35-36$. Generative nucleus of pollen-grain surrounded by vacuole and sheath of cytoplasm. $\times \mathrm{I} 450$. 
Annats of Botany,
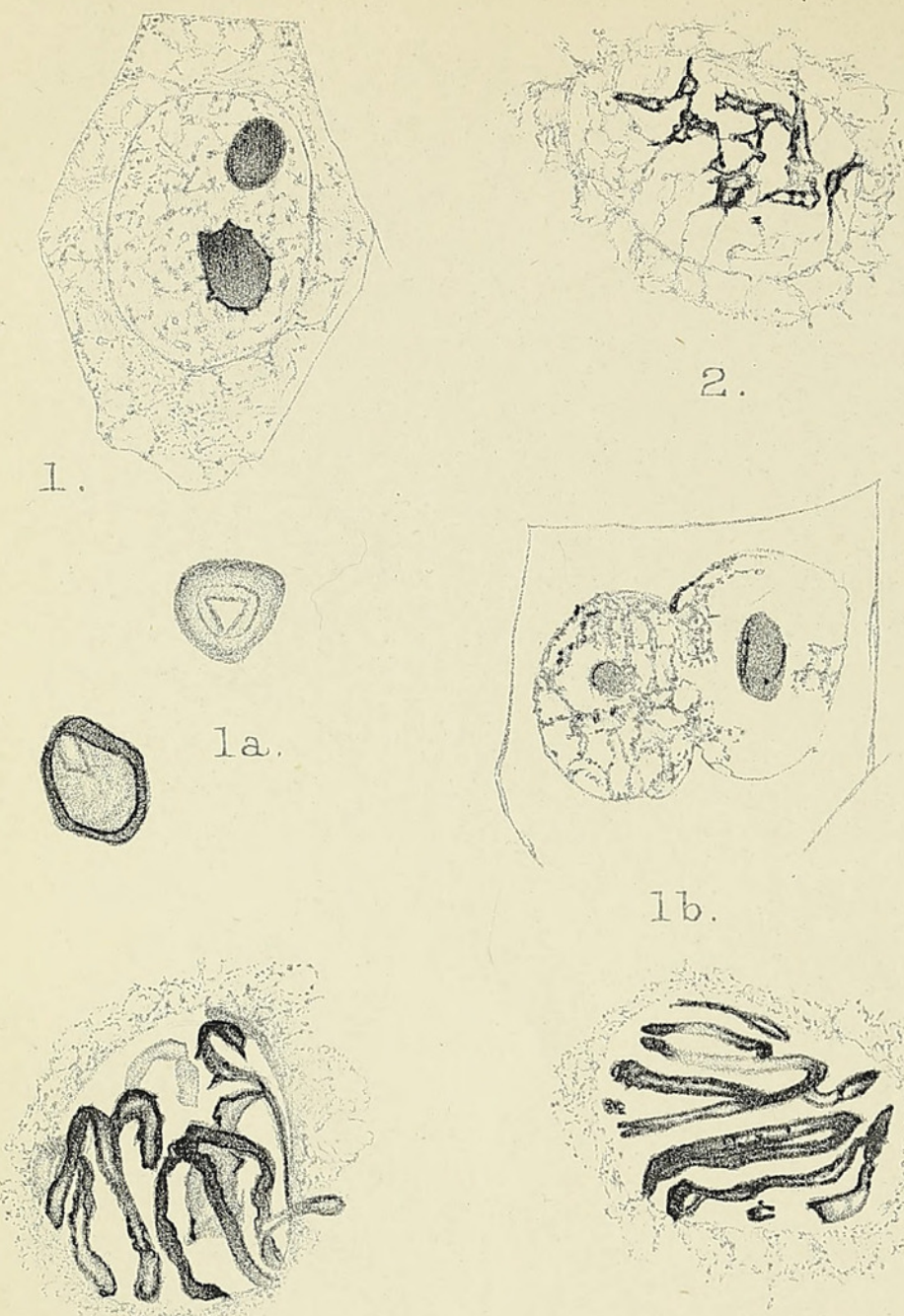

11.
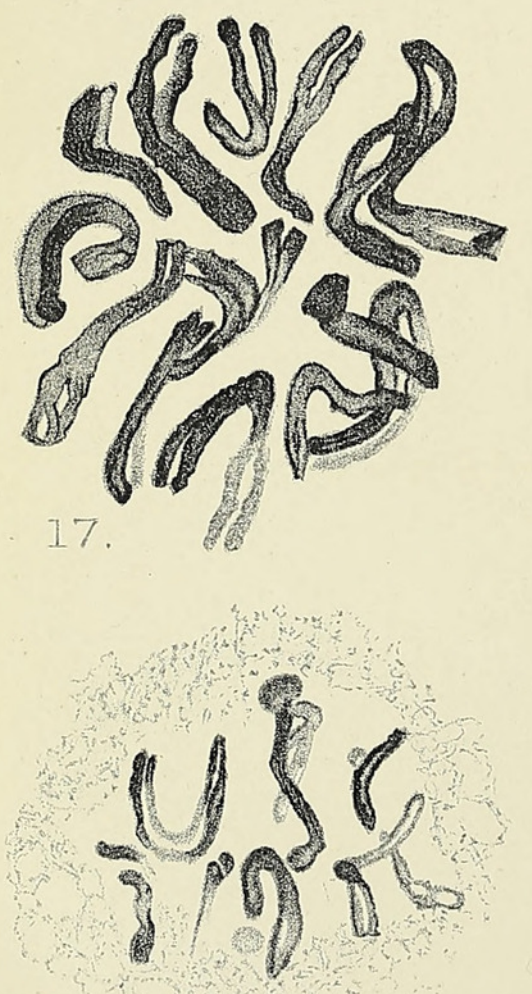

$1 \mathrm{~b}$

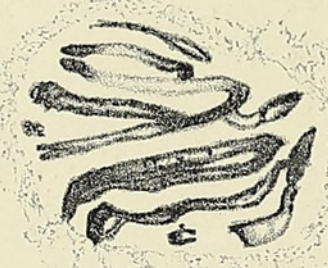

12.

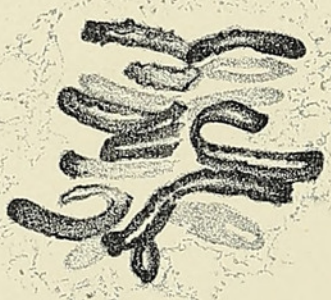

18

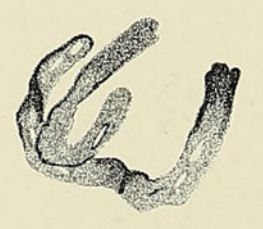

21.
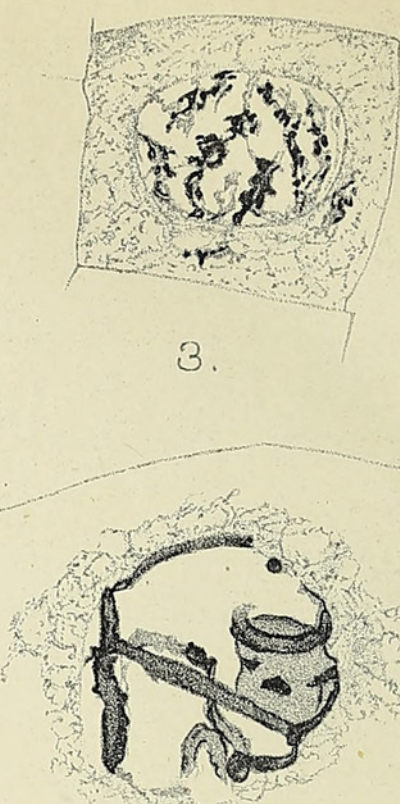

7.

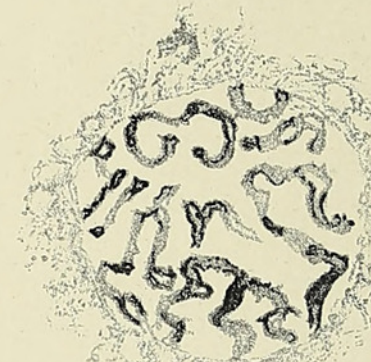

13.

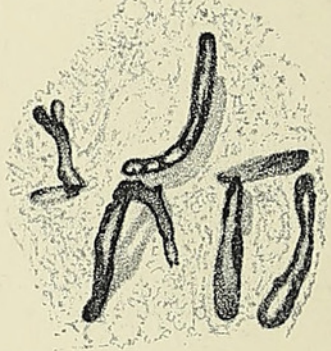

19

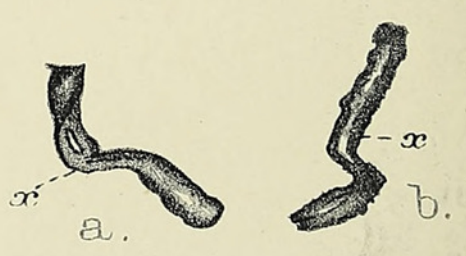

22. 


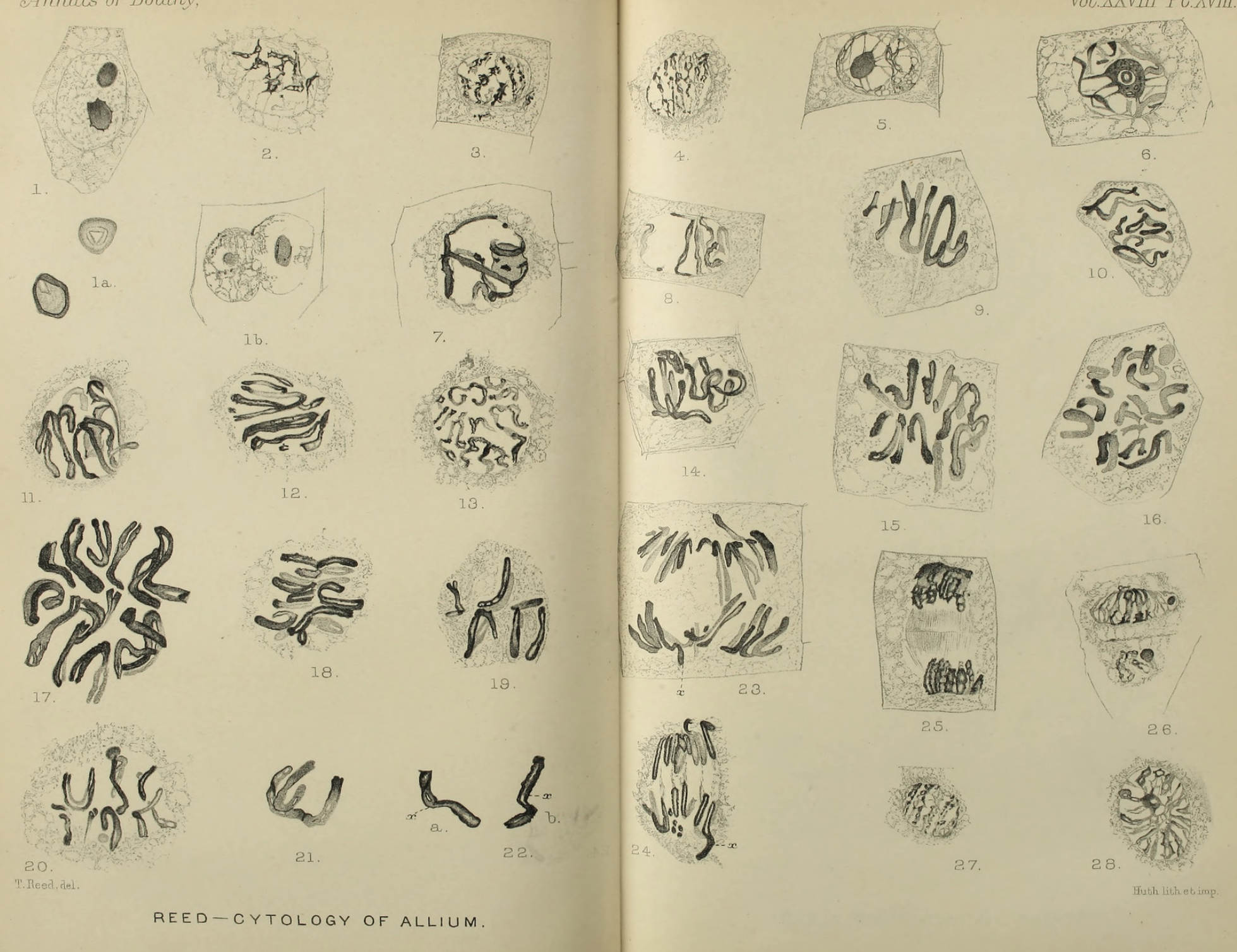


Annals of Botany,

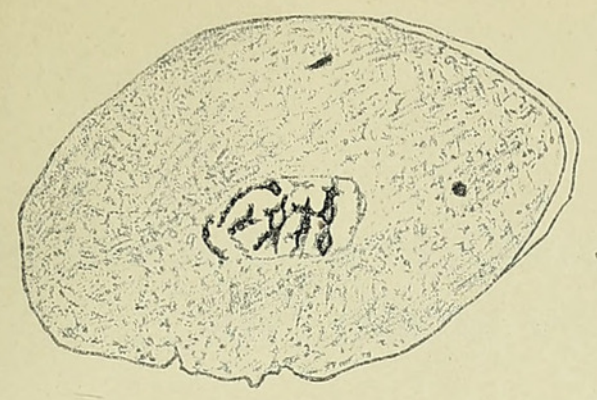

29.
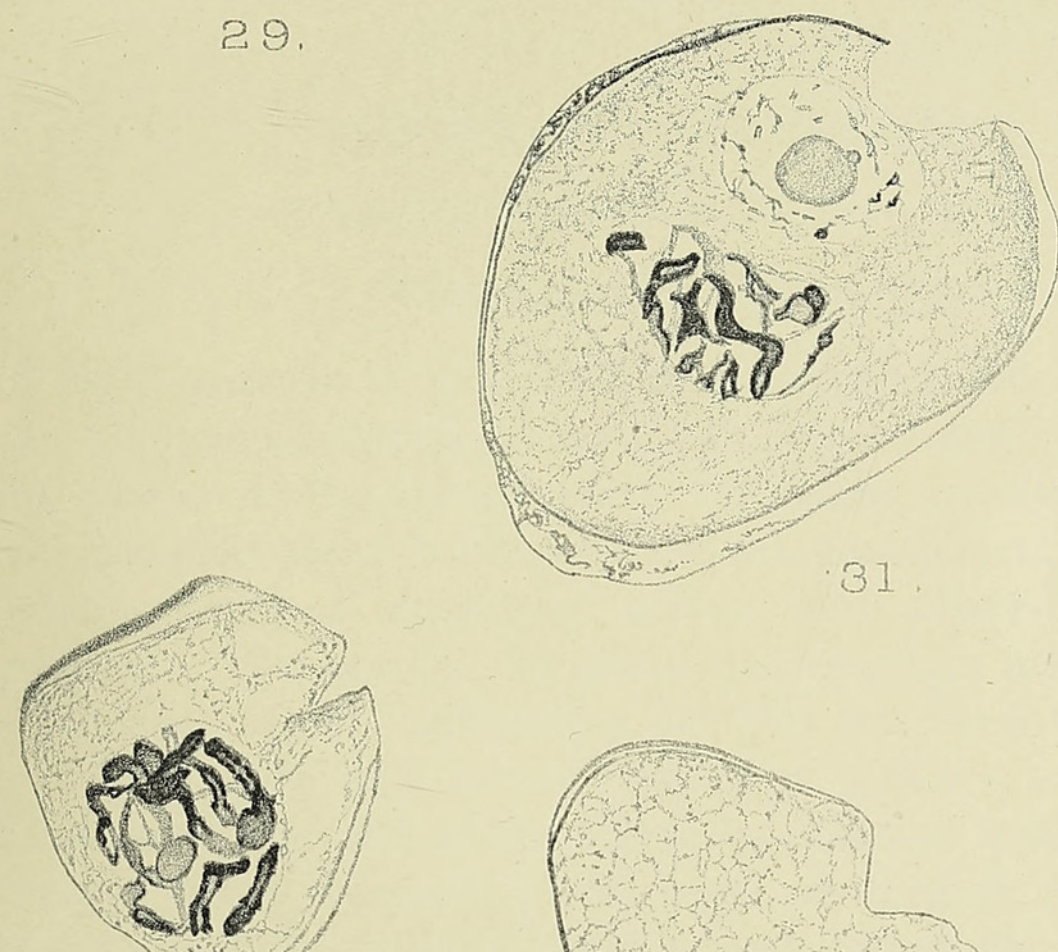

32.

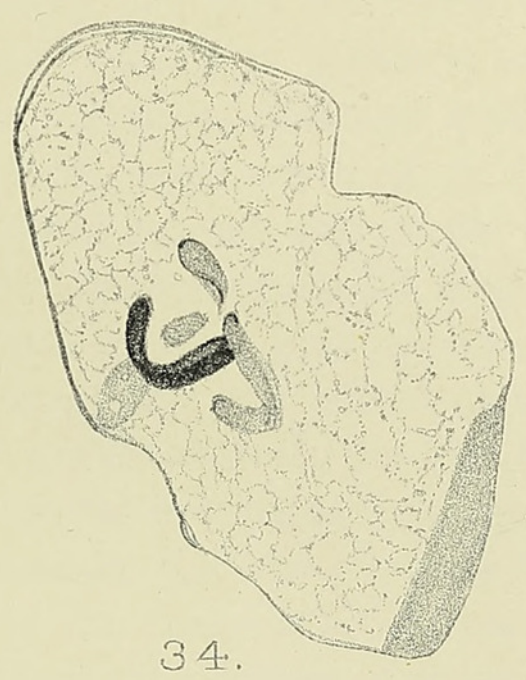

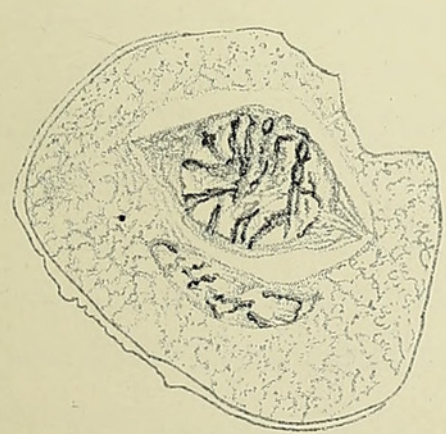

35.

T.Re日d, del.

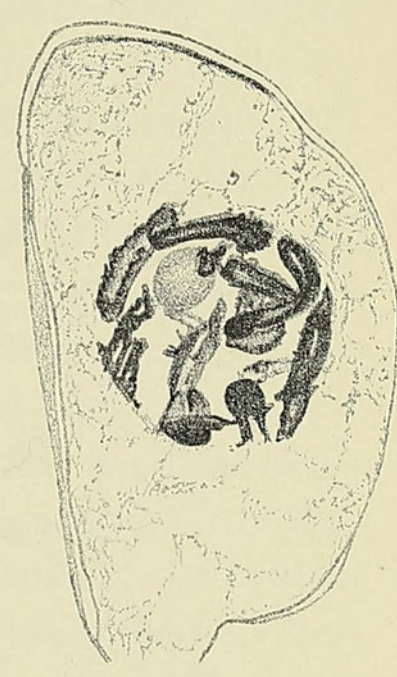

33

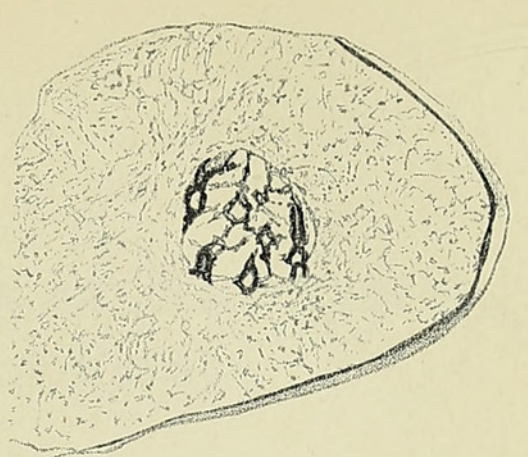

30.

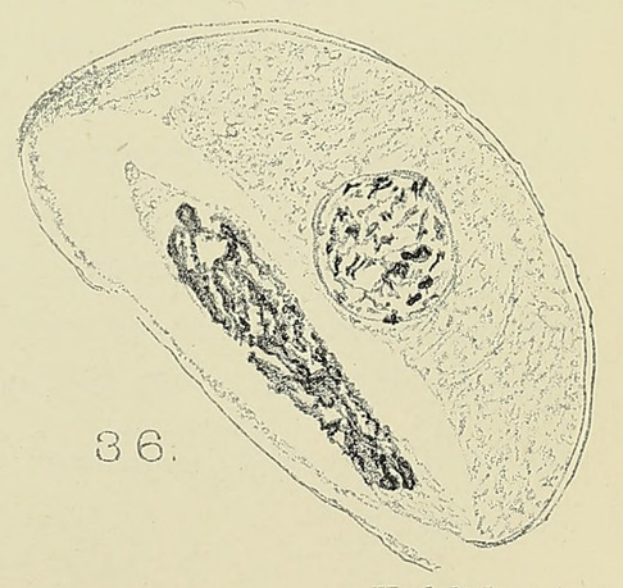

REED-CYTOLOGY OF ALLIUM. 


\section{$2 \mathrm{BHL}$ Biodiversity Heritage Library}

Reed, T. 1914. "The nature of the double spireme in Allium cepa." Annals of botany 28, 271-281. https://doi.org/10.1093/oxfordjournals.aob.a089504.

View This Item Online: https://www.biodiversitylibrary.org/item/236856

DOI: https://doi.org/10.1093/oxfordjournals.aob.a089504

Permalink: https://www.biodiversitylibrary.org/partpdf/320022

\section{Holding Institution}

Smithsonian Libraries

\section{Sponsored by}

Biodiversity Heritage Library

\section{Copyright \& Reuse}

Copyright Status: Not in copyright. The BHL knows of no copyright restrictions on this item.

This document was created from content at the Biodiversity Heritage Library, the world's largest open access digital library for biodiversity literature and archives. Visit BHL at https://www.biodiversitylibrary.org. 